\title{
Turun Melayu: Konstruksi Identitas Orang Dayak Muslim di Desa Kuala Rosan Kalimantan Barat
}

\author{
Af'idatul Lathifah \\ Program Studi Antropologi Sosial, Fakultas Ilmu Budaya, Unversitas Diponegoro Semarang \\ Korespondensi: afidatullathifah@gmail.com
}

\begin{abstract}
The province of West Kalimantan is known as a province inhabited by Dayak etnhnic. However, it cannot be denied that Malay also became the ethnic group dominated the province. The existence of Malay also brings new religion to Dayak, namely Islam. The conversion of the Dayak religion into a Muslim certainly has cultural consequences. Dayak customs that are in part contrary to Islamic teachings must certainly be abandoned. Going down to Malays is the choice of Dayaks when they embrace Islam. Religious conversion is also followed by the conversion of culture, thus forming a new cultural community that is different from the Dayak and at the same time different from the Malays.
\end{abstract}

Keywords: identity, Dayak,turun Malay, Islam

\section{Pendahuluan}

Saat mendengar kata 'Kalimantan', seringkali diasosiasikan dengan kata 'Dayak' karena memang salah satu suku bangsa yang terkenal berasal dari Kalimantan adalah suku bangsa Dayak. Akan tetapi, tentu saja tidak bisa dipungkiri bahwa keberadaan suku bangsa lain juga turut memperkaya khasanah kebudayaan Kalimantan, salah satunya adalah suku Bangsa Melayu. Menurut data BPS tahun 2003, prosentase etnis Melayu dan Dayak di Kalimantan Barat seimbang yaitu sebesar 33,75\%. Hal ini menunjukkan bahwa antara Dayak dan Melayu keduanya memberikan warna budaya di Kalimantan Barat.

Walker (2004) mencoba menelusuri keberadaan Melayu di Pulau Kalimantan. Menurutnya orang Melayu berasal dari Kesultanan Malaka di Johor yang memperluas kekuasaannya di Borneo dan menduduki Kesultanan Brunei. Dari sanalah identitas Melayu mulai dipakai dan menyebar ke seluruh wilayah Pulau Kalimantan. Sedangkan penduduk asli Kalimantan sendiri adalah orang Dayak. Keberadaan suku bangsa Melayu, juga tidak terlepas dari masa-masa keemasan kesultanan Melayu yang tersebar di Pulau Kalimantan. Mulai dari Kesultanan Pasir, Kesultanan Pontianak, Kesultanan Bulungan dan sebagainya. Hingga saat ini, peninggalan-peninggalan kesultanan terdahulu di Pulau Kalimantan masih bisa ditemukan, dan bahkan beberapa kesultanan masih berjalan dengan system pemerintahan dan kebudayaannya.

Keberadaan suku bangsa Melayu tersebut, sangat identik dengan penyebaran agama Islam di Pulau Kalimantan. Hanya saja, sebagian besar kesultanan awal mulanya mengekspansi wilayah pesisir saja, sehingga perkembangan Islam lebih banyak terjadi di daerah pesisir. Akan tetapi, tentu saja seiring berjalannya waktu, penyebaran Islam mencapai dataran pedalaman Kalimantan dan menyentuh komunitas-komunitas Dayak yang mayoritas berada di wilayah pedalaman.

Persoalan kultural antara identitas suku bangsa dan identitas keagamaan pun ditemui oleh orang Dayak yang memeluk Islam. Kultur Dayak yang seringkali bertentangan dengan 
ajaran agama Islam tentu saja tidak dapat lagi dipraktekkan oleh orang-orang Dayak yang sudah menjadi muslim. Turun Melayu, adalah salah satu upaya orang Dayak pemeluk agama Islam untuk dapat terus menjalankan ajaran agama sekaligus memiliki identitas kultural yang diakui. Artikel ini akan menguraikan bagaimana kehidupan kultural, praktek-praktek apa saja yang dijalani, serta berbagai dinamika kehidupan Muslim Dayak di Desa Kuala Rosan, Kecamatan Meliau, Kabupaten Sanggau, Kalimantan Barat.

Budaya oleh Barth (1998) diidentifikasi sebagai penggambaran perilaku manusia, sehingga ketika sekelompok masyarakat memiliki perilaku yang serupa maka ia akan diidentifikasi sebagai kelompok etnis tertentu. Kelompok etnis tersebut berperilaku sesuai dengan sistem kebudayaan mereka. Secara gamblang, Geertz (1973) menyebutkan bahwa kebudayaan merupakan sistem simbol yang dipakai oleh suatu kelompok masyarakat. Simbolsimbol tersebut disepakati antar individu sehingga terjadi keteraturan dalam ekspresi kehidupan. Ketika seseorang memutuskan untuk mengubah budaya mereka, maka berarti pula mereka mengubah sistem simbol yang mereka percayai selama ini.

Perubahan kebudayaan oleh bisa disebabkan oleh berbagai hal. Abdullah (2006) menyebutkan perubahan kebudayaan disebabkan oleh tiga hal; 1) mencairnya sekat-sekat kebudayaan, 2) politik ruang dan makna budaya, 3) hegemoni kekuasaan yang berubah. Hegemoni kekuasaan bisa juga ditampilkan oleh agama. Perubahan yang terjadi di masyarakat bisa jadi merupakan perubahan yang dikehendaki oleh karena perubahan tersebut telah direncakan sebelumnya oleh masyarakat (Soemardjan, 1974). Ajaran agama yang harus diikuti oleh pengikutnya karena adanya klaim-klaim kebenaran (truth claim) membuat para pengikutnya harus membiasakan diri. Jika agamanya berubah maka bisa jadi kebudayaannya juga berubah. Perubahan keagamaan ini tentu saja dilakukan secara sadar sehingga menjadi perubahan yang dikehendaki. Maka perubahan kebudayaan mereka juga merupakan perubahan yang telah dipertimbangkan sebelumnya.

Kebudayaan inilah yang pada akhirnya menjadi identitas individu. Hall (1990) mengemukakan dua hal yang mendasari identitas budaya. Identitas budaya dapat dilihat dari dua cara pandang, yaitu identitas budaya sebagai wujud (identity as being) dan identitas budaya sebagai proses menjadi (identity as becaming). Lebih lanjut Hall (1996) menyebutkan bahwa identitas ini bisa juga digunakan sebagai politik identitas. Politik identitas selalu berhubungan dengan definisi diri (the definition of self) yang merupakan pemahaman bahwa identitas individu didasarkan pada tempat atau posisi dimana individu tersebut diletakkan (place-based identity).

\section{Metode}

Penelitian ini merupakan penelitian etnografi. Tujuan dari penelitian etnografi adalah untuk mendapatkan sudut pandang dari pelaku budaya secara holistik. Untuk itu, penelitian tidak hanya dilakukan dengan pengamatan saja, tetapi ada keterlibatan penuh peneliti sehingga bisa mendapatkan realita kebuayaan baik dalam pola perilakunya maupun pola kognitifnya. Geertz (1983) menyatakan sebagai 'to grasp native's point of view'.

Peneliti telah melakukan observasi partisipasi dengan tinggal di Desa Kuala Rosan selama 2 bulan yaitu pada September-Desember 2013, mengikuti segala aktivitas yang dilakukan oleh pendududk desa, mengamati fenomena-fenomena yang berhubungan dengan topik penelitian dan melakukan wawancara, baik wawancara informal maupun wawancara terstruktur. Wawancara secara mendalam dilakukan untuk mendapatkan konfirmasi atas hasil observasi dan juga untuk mendapatkan informasi lain yang tidak bisa didapatkan dari observasi (Spradley: 2007). 


\section{Hasil \& Pembahasan}

\subsection{Kuala Rosan, Pemukiman Muslim di Tengah-tengah Etnis Dayak}

Senja hari di Desa Kuala Rosan tidak berbeda dengan senja di pemukiman-pemukiman Muslim lainnya di Indonesia. Adzan berkumandang dari satu-satunya musola di desa tersebut. Anak-anak berlarian ke dalam rumah, bergegas mengambil mukena dan Al-Quran, lantas berjalan menuju musola. Mereka akan melaksanakan sholat magrib berjamaah yang dilanjutkan dengan belajar mengaji bersama seorang ustadz.

Tidak banyak orang yang hadir dalam jamaah magrib tersebut, justru jamaah sholat didominasi oleh anak-anak berusia 5 tahun hingga 10 tahun berjumlah 15 anak. Selebihnya, hanya ada sang ustadz sebagai imamnya, dan satu atau dua jamaah dewasa lainnya. Selepas sholat, anak-anak lantas duduk berjajar rapi, membuka kitab Al-Quran dan mulai membaca doa untuk mengawali kegiatan belajar mengaji mereka. Lantas satu per satu maju ke hadapan sang ustadz dan menyetorkan bacaan Al-Quran mereka. Sesekali terdengar teguran dari ustadz karena kesalahan mereka dalam membaca Al-Quran. Setelah pelajaran mengaji selesai, dilanjutkan dengan berjamaah sholat Isya. Setelahnya, para jamaah pun pulang ke rumah masing-masing.

Desa Kuala Rosan, sesuai dengan namanya 'kuala' yang berarti sungai dan 'rosan' yang merupakan nama sungai, adalah sebuah desa yang terletak di pinggir sungai Rosan. Untuk menempuh desa tersebut dari Pontianak, diperlukan waktu hingga seharian penuh. Perjalanan dari Kota Pontianak dimulai dengan menaiki bus antar kota ke ibukota Kecamatan Meliau selama kurang lebih 8 jam. Selanjutnya dari Meliau bisa menaiki perahu motor (ketinting) selama kurang lebih 4 jam menuju salah satu pemukiman transmigran Bina Harapan Desa (BHD). Perjalanan dilanjutkan menggunakan perahu sampan bermotor menuju Desa Kuala Rosan selama kurang lebih 3 jam, dengan catatan debit air sungai cukup tinggi. Jika air sungai dangkal, maka perjalanan tersebut akan memakan waktu lebih panjang lagi karena bisa jadi perahu harus karam karena sungai yang dangkal.

Awal terbentuknya Desa Kuala Rosan konon karena kedatangan seorang tua bernama Kek Jaya, seseorang yang beretnis Dayak. Ia berasal dari Sekadau, sebuah desa di hulu sungai Buayan. Keturunan-keturunan Kek Jaya inilah yang kini meninggali dua desa, yaitu Kuala Rosan dan Lubuk Piling. Lambat laun, penduduk dari desa lain pun mendatangi Desa Kuala Rosan dan Lubuk Piling karena kedua desa tersebut sebenarnya terletak di wilayah yang dianggap strategis. Kedua desa tersebut terletak di hilir bertemunya dua sungai, sehingga menjadi jalur transportasi yang strategis. Desa Lubuk Piling lambat laun didominasi oleh pendatang beretnis Dayak, sedangkan Kuala Rosan ditinggali oleh keturunan Kek Jaya.

Desa Kuala Rosan ditempati oleh 105 kepala keluarga dengan total penduduk sebanyak 360 jiwa. Mayoritas mata pencaharian penduduk di desa tersebut adalah petani karet dan sawit, baik pemilik tanah maupun hanya sekedar buruh tani. Pemilik tanah yang juga memiliki modal uang tunai yang besar selain tetap bertani karet dengan mempekerjakan buruh, mereka juga menjelma menjadi tengkulak atau disebut sebagai tokay. Tengkulak ini membeli karet dari petani, menyediakan kebutuhan pertanian, menjual kebutuhan-kebutuhan rumah tangga, sekaligus juga memberikan pinjaman uang tunai kepada para penduduk.

Untuk menyadap karet, penduduk Desa Kuala Rosan akan berangkat bekerja saat masih dini hari, antara pukul 03.00 hingga pukul 04.00. Karet tidak akan maksimal disadap jika matahari sudah muncul, karena getah karet bisa menjadi kering. Aktivitas menyadap karet dimulai dengan menyayat kulit pohon karet sehingga mengeluarkan getah. Getah ditampung dalam wadah seadanya, kadang batok kelapa, bekas gelas mineral, ataupun wadah plastik bekas lainnya, atau bahkan daun yang dilipat membentuk corong. Selanjutnya, setelah getah dirasa cukup, getah tersebut dikumpulkan dan dicetak menjadi lembaran-lembaran pipih. 
Pencetakan getah memakan waktu seharian, sehingga mereka tidak menunggui getah membeku. Setelah membeku, hari selanjutnya getah tersebut dibawa ke sungai untuk direndam. Perendaman bisa berlangsung selama berbulan-bulan, jika dirasa jumlahnya sudah mencukupi untuk dijual maka barusal rendaman karet tersebut dipanen. Kegiatan mengolah karet ini rata-rata berakhir pukul 10.00 .

Perjalanan menuju perkebunan karet pun tidak selalu mudah dan singkat, rata-rata diperlukan waktu sekitar 1 jam, baik dengan berjalan kaki maupun dengan perahu dayung untuk menuju kebun mereka. Di kebun, biasanya mereka memiliki gubuk kecil untuk beristirahat amupun menaruh barang bawaan mereka. Sarapan pun seiringkali dilakukan di gubuk tersebut. Bekal makanan yang mereka bawa biasanya nasi dan mi instan mentah yang dicampur bumbu sebagai lauknya. Terkadang mereka juga memasak sayur yang dipetik saat perjalanan berangkat ke kebun. Sayur-sayuran yang didapat berupa paku-pakuan, rebung, kangkung liar, atau bahkan daun karet muda. Mata pencaharian pokok lainnya adalah perkebunan sawit. Akan tetapi, kebun sawit memang baru muncul sekitar tahun 1996. Sayangnya, sulitnya kases untuk menjual sawit tersebut membuat petani sawit tidak menggarap sawit dengan baik. Akses transportasi baik darat maupun air yang tidak memadai membuat sawit membusuk di perjalanan, sehingga harga jualnya rendah. Tidak sebanding dengan biaya pengolahan dan transportasi penjualan.

Satu-satunya desa Dayak yang berbatasan langsung dengan Desa Kuala Rosan memang hanya Desa Lubuk Piling. Akan tetapi, hampir seluruh desa yang berada tidak jauh dari Kuala Rosan merupakan desa yang dihuni oleh etnis Dayak. Hal ini menguatkan bahwa masyarakat muslim menjadi minoritas di wilayah tersebut. Komunitas muslim lainnya biasanya hanya ditemukan di desa-desa transmigrasi yang letaknya lebih dekat ke wilayah perkotaan.

\subsection{Kegiatan Keagamaan}

Kegiatan keagamaan sehari-hari selain ibadah wajib adalah pengajian pada hari Jumat. Dengan kondisi pekerjaan yang mereka lakukan, nyatanya hampir sebagian besar warga Muslim di Kuala Rosan tidak melakukan sholat wajib, khususnya sholat Subuh yang memang dikerjakan di pagi hari, waktu yang mereka gunakan untuk bekerja.

Hari Jumat biasanya dimanfaatkan untuk melakukan berbagai kegiatan keagamaan ataupun perayaan hari besar Islam yang sekalipun tidak selalu jatuh di hari Jumat. Alasannya, karena pada hari Jumat, para lelaki akan menghentikan kegiatan harian mereka untuk sholat Jumat berjamaah sehingga warga lebih mudah dikumpulkan. Khusus untuk perempuan, setiap hari Jumat diadakan pengajian setelah waktu Ashar atau kira-kira pukul 4 sore. Pengajian yang dimaksud adalah pembacaan surat Yasin dan tahlil. Pengajian diadakan di rumah-rumah warga sesuai dengan giliran yang disepakati.

Pada setiap bulan Sya'ban (bulan sebelum Ramadhan dalam kalender hijriah), masyarakat akan mengadakan acara Berowah. Berowah diambil dari kata 'ruwah', yang merupakan kata lain untuk menyebut bulan Sya'ban. Berowah dilakukan untuk mendoakan roh-roh pendahulu atau orang tua yang sudah meninggal. Acara Berowah juga dimulai dengan pembacaan tahlil dan diakhiri dengan makan bersama. Makanan diberikan oleh orang yang mengundang Berowah tersebut, biasanya satu keluarga yang masih dalam satu garis keturunan. Dalam satu bulan tersebut, Berowah bisa dilakukan beberapa kali, tergantung seberapa banyak keluarga yang mengadakan acara.

\subsection{Turun Melayu, Identitas Baru Dayak Muslim}

Seseorang yang berpindah agama Islam umumnya disebut sebagai muallaf. Pada bahasa keseharian, dalam bahasa Indonesia disebut dengan 'masuk Islam'. Kata yang digunakan 
adalah masuk sebagai lawan kata dari keluar. Keluar dari agama tertentu dan masuk ke agama Islam. Kata 'masuk' ini lebih berkonotasi positif ketimbang kata 'keluar' karena kata 'masuk' digunakan oleh penganut agama yang dimasukinya. Sehingga orang yang masuk ke agama tertentu dianggap berhijrah ke jalan hidup yang lebih baik.

Masuknya Islam ke Kuala Rosan kabarnya karena kedatangan dua pedagang Melayu dari Banjar yaitu Datuk Encik Tayip dan Haji Sabran. Mereka berdua datang pada tahun 1920an dan kemudian mendirikan sebuah rumah di Desa Kuala Rosan. Selain mendirikan rumah, mereka juga melakukan aktivitas berdagang disana. Awalnya mereka membeli hasil hutan, damar juga rotan yang dikumpulkan oleh warga. Sambil berdagang mereka juga menyebarkan agama Islam. Hingga saat ini, masih ada keluarga yang mengaku sebagai keturunan Datuk Taip dan Haji Sabran.

Lambat laun, masyarakat Desa Kuala Rosan satu persatu memeluk agama Islam, sehingga desa tersebut mayoritas dihuni oleh orang Islam. Masyarakat lain yang belum memeluk Islam perlaha juga 'menyingkir' berpindah ke desa-desa lain di sekitar Kuala Rosan, salah satunya tentu Desa Lubuk Piling. Sebaliknya, orang Dayak yang memeluk agama Islam juga berpindah ke Desa Kuala Rosan.

Encik Tayyib dan Haji Sabran sebagai penyebar agama di wilayah tersebut juga turut membawa kultur baru, yaitu kultur Melayu. Melayu memang sudah identik dengan agama Islam. Aspek-aspek identitas budayanya telah banyak yang disesuaikan dengan syariat agama Islam. Sebaliknya, aspek-aspek identitas budaya Dayak banyak yang bertentangan dengan syariat Islam. Agama atau kepercayaan awal Dayak adalah kaharingan, kepercayaan yang mempercayai dewa Ranying Hatalla. Dalam kepercayaan ini, masyarakat Dayak mempercayai reinkarnasi manusia pada makhluk hidup lainnya. Kepercayaan ini juga tidak mengenal adanya surga dan neraka. Tentu saja kepercayaan ini bertolak belakang dengan syariat Islam yang tidak mempercayai reinkarnasi tetapi meyakini adanya surga dan neraka.

Orang Dayak yang memeluk agama Islam dan tinggal di Desa Kuala Rosan mengidentifikasi diri mereka sebagai orang Melayu. Menjadi Melayu berarti juga meninggalkan adat istiadat atau kebiasaan mereka ketika masih menyandang etnis Dayak. Proses perpindahan agama dari kepercayaan kaharingan mejadi Islam ini juga diikuti dengan proses perubahan etnis, yaitu dari Dayak menjadi Melayu. Perpindahan agama tetap dibahasakan dengan 'pindah' atau 'masuk' Islam, sedangkan perpindahan etnis disebut dengan 'turun' Melayu. Penggunaan kata 'turun' ini merupakan bentuk hegemoni budaya Dayak yang menjadi mayoritas di wilayah tersebut. 'Turun' berarti menempati kedudukan yang lebih rendah, sehingga secara tidak langsung menyatakan bahwa Dayak merupakan etnis yang keududukannya lebih tinggi.

Ketika seseorang telah masuk Islam maka ia sebisa mungkin melaksanakan ajaran Islam, melakukan perintah Tuhan dan menjauhi larangannya. Larangan-larangan dalam Islam inilah yang sering berbenturan dengan adat Dayak. Tuak dan daging babi merupakan hidangan wajib dalam setiap perjamuan adat Dayak. Tuak beras, minuman tradisional Dayak yang terbuat dari beras ketan mengandung alkohol dan memabukkan

\subsection{Hubungan dengan Orang Dayak}

Sebagai sebuah perkampungan muslim di tengah-tengah mayoritas suku bangsa Dayak, persinggungan dengan orang Dayak tentu tidak dapat dihindari. Apalagi, Desa Kuala Rosan berbatasan langsung dengan sebuah perkampungan Dayak. Begitu juga dengan kehidupan sehari-hari, mau tidak mau mereka harus saling berhubungan satu sama lain.

Hubungan antar kedua etnis tersebut seringkali terjadi saat perhelatan agenda-agenda besar, seperti pesta pernikahan dan pesta Gawai Adat. Setiap kali orang Dayak mengadakan acara Gawai (pesta panen tahunan) maka orang Kuala Rosan akan selalu berpartisipasi. 
Partisipasi utama yang mereka lakukan adalah mengikuti turnamen-turnamen olahraga yang selalu digelar pada saat pra Gawai berlangsung. Selanjutnya, di malam puncak Gawai yang biasanya diisi dengan gelaran pasar malam, warga Kuala Rosan pun selalu antusias untuk mendatangi. Muslim Kuala Rosan juga sering mendapatkan undangan pernikahan dari orang Dayak. Dalam hal ini, terlihat jelas bentuk toleransi keduanya. Orang Dayak yang mengundang orang Muslim akan menyediakan makanan halal di samping makanan-makanan tradisional orang Dayak, sehingga si muslim tidak khawatir atau ragu-ragu menyantap makanan tersebut.

Beberapa desa Dayak, yang memiliki satu aliran sungai yang sama dengan Desa Kuala Rosan, akan memberitahukan terlebih dahulu kepada kepala Desa Kuala Rosan jika mereka akan mengadakan peyembelihan babi besar-besaran untuk keperluan adat. Dengan demikian warga muslim Kuala Rosan akan 'libur' memanfaatkan sungai pada hari tersebut, yang airnya bercampur dengan darah babi. Sekalipun sebenarnya dalam ketentuan ajaran Islam sendiri, air sungai yang mengalir tidak akan najis jika bercampur dengan barang najis sekalipun. Akan tetapi, hal tersebut menunjukkan toleransi antar kedua belah pihak.

Muslim Kuala Rosan juga sebagian besar masih memiliki nenek moyang atau saudara yang bersuku bangsa Dayak. Memang seringkali ketika sudah memeluk agama Islam, maka orang tersebut juga akan pindah ke desa lain yang penduduknya mayoritas muslim, tetapi hubungan kekeluargaan tetap tidak akan putus jika si muslim memang mendapat restu dari keluarganya untuk memeluk agama Islam. Bahkan beberapa orang Islam di Kuala Rosan pun mengangkat anak dari keluarganya yang Dayak dengan harapan si anak kelak akan turut memeluk Islam. Hal ini dilakukan oleh keluarga Pak Sukardi. Ia mengangkat salah satu keponakannya sejak masih bayi. Awalnya karena alasan ekonomi orang tua keponakannya tersebut. Tetapi Pak Sukardi memiliki misi tersendiri, yaitu ingin si anak memeluk agama Islam juga. Untuk itu, sehari-harinya, Pak Sukardi selalu mendorong anak angkatnya tersebut untuk melakukan ibadah sholat dan belajar mengaji di musola.

Ketegangan antara Muslim Melayu dengan orang Dayak bukanlah hal yang tidak terjadi. Ketegangan tersebut seringkali terlihat namun masih tersembunyi. Misalnya, orang Muslim Kuala Rosan seringkali memberikan stereotip bagi orang Dayak, orang Dayak diberi cap sering menyiksa hewan karena ketika akan mengkonsumsi anjing mereka sering memukul anjing hingga mati. Konflik ini menurut Tockary (2003), perpindahan agama di masa pramodern dianggap sebagai pengingkaran terhadap agama dan pengkhianatan terhadap masyarakat. Untuk itulah berbagai macam ketegangan bisa terjadi, baik dari pihak muslim maupun pihak Dayak sendiri.

\section{Menjadi Muslim Meninggalkan Dayak}

Praktek keagamaan yang dilakukan oleh muslim Kuala Rosan memang belum mengikuti ajaran Rukun Islam yang sebenarnya. Selain masih belum melaksanakan sholat wajib lima waktu setiap hari, mereka juga masih jarang mempraktekkan puasa. Alasan utamanya adalah pekerjaan mereka yang cukup sulit dan membutuhkan banyak tenaga. Alasan lainnya adalah keberadaan listrik yang masih sangat terbatas, sehingga pelaksanaan ibadah tidak maksimal.

Selain masih minimnya praktek keagamaan, sebagian muslim Kuala Rosan juga masih mengkonsumsi minuman keras dan juga bermain judi. Kegiatan tersebut tidak hanya dilakukan pada saat mereka mengikuti Gawai (karena memang umumnya saat Gawai dua hal tersebut marak dilakukan), tetapi juga dilakukan sehari-hari. Akan tetapi, konsumsi daging babi memang sudah banyak ditinggalkan. Sekalipun demikian, perayaan hari besar keagamaan tetap dilaksanakan dengan meriah di Kuala Rosan. Selain Berowah, tradisi silaturahmi ketika Hari Raya Idul Fitri juga tetap terlaksana, apalagi ketika mereka memiliki saudara di luar Desa Kuala Rosan. 
Hanya saja, muslim di Kuala Rosan berusaha meninggalkan beberapa tradisi Dayak seperti makan babi, memakan binatang buruan yang tidak halal. Kebutuhan protein mereka dipenuhi dengan ternak ayam sendiri atau mencari sumber protein dari sungai seperti udang dan ikan. Mereka mulai memisahkan makanan yang halal dengan yang haram. Mereka juga tidak lagi memelihara anjing sebagaimana lazim dilakukan setiap keluarga Dayak, karena anjing dinilai sebagai hewan yang najis sesuai dengan tuntunan ajaran Islam.

Selain meninggalkan sebagian besar tradisi Dayak, muslim Kuala Rosan juga mengganti Bahasa mereka menjadi Bahasa Melayu. Pakaian adat yang biasa dipakai dalam upacara pernikahan pun juga mengambil pakaian adat Melayu. Begitu juga dengan dekorasinya, warna kuning yang merupakan warna khas kebudayaan Melayu, selalu mendominasi ketika muslim Kuala Rosan mengadakan pesta pernikahan. Mereka juga mengganti panggilan kepada orang yang dituakan, pemuka agama, atau orang yang disegani dengan sebutan 'datuk', sebutan yang berasal dari Bahasa Melayu.

\section{Kesimpulan}

Konversi keagamaan yang dilakukan oleh orang Dayak diikuti juga dengan konversi identitas etnis menjadi Melayu. Orang Dayak yang memeluk agama Islam ini menyebut dirinya sebagai turun melayu. Selain menjalankan praktek keagamaan sesuai dengan tuntunan Islam, orang Dayak yang memeluk Islam juga meninggalkan adat-istiadat Dayak mereka dan mengganti dengan adat istiadat Melayu. Sekalipun demikian, beberapa kebiasaan yang juga dilakukan oleh orang Dayak tetap diikuti oleh orang muslim Melayu di Kuala Rosan. Mengingat wilayah hidup mereka yang saling berdampingan. Identitas Melayu menjadi identitas yang penting bagi orang Dayak yang beragama Islam, karena identitas tersebut tidak hanya mengakomodasi keislaman mereka, tetapi juga mengakomodasi kultur mereka.

\section{Daftar Pustaka}

Hall, Stuart. 1990. The Question of Cultural Identity. dalam Modernity and It's Future, hal. 274-316. Cambridge: Polity Press

. 1997. Representation: Cultural Representation an sisgnifying practices.

California: Sage in Association with the Open University

Geertz, Clifford. 1973. The Interpretation of Culture. New York: Basic Books

1983. "From The Native's Point of View". On The Nature of Anthropological Understanding in Local Knowlegde: Further Essay in Interpretive Anthropology. New York: Basic Books.

Soemardjan dan Soleman, Soemardi (ed). 1974. Setangkai Bunga Sosiologi. Jakarta: Yayasan Badan Penerbit Fakultas Ekonomi UI

Spradley, James P. 1972. Culture and Cognition: Rules, Maps and Plans. New York : Chandler Publishing Company. . 2007. Metode Penelitian Etnografi. Jakarta: Tiara Wacana

Tockary, R. 2003. "Catatan Singkat tentang Konflik Etnis-Agama di Indonesia" dalam Konflik Komunal di Indonesia Saat ini. Jakarta: Indonesian-Netherlands Corporation in Islamic Studies 
Endogami: Jurnal Ilmiah Kajian Antropologi Vol. 2 No. 1 : Desember 2018

E-ISSN : 2599-1078

Walker, J.H. "Autonomy, Diversity, and Dissent : Conception of Power and sources of action in the 'Sejarah Melayu' (Raffless MS 18)" dalam Theory and Society, Vol. 33, No. 2 (Apr., 2004), pp. 213-255 